\title{
THE SECESSION OF SINGAPORE FROM MALAYSIA: A HISTORICAL INTERPRETATION OF THE NOVEL SATU BUMI
}

\author{
Sohaimi Abdul Aziz \\ soazz@usm.my \\ School of Humanities, \\ Universiti Sains Malaysia, \\ 11800 USM, Penang, Malaysia. \\ Tel.:+604-65333858
}

\begin{abstract}
History has often become the inspiration for writers, as it has for Isa Kamari in the case of his novel Satu Bumi (One Earth) (1998). What were the historical sources for this author, and how were they employed in his fiction? What was the author's aim in fictonalizing these historical sources? These are the questions that receive attention in this paper. Using a historical approach and textual analysis, the historical facts found in the novel Satu Bumi and the author's aims behind fictionalizing them are examined in this study. The study finds that the novel Satu Bumi is based on the history of Malaysia and Singapore, and fictionalizes the historical events using elements of romance and drama. However, even in this romantic and dramatic setting, the historical elements used do not merely serve to record the history of Malaysia and Singapore but are also employed to predict the future of the Malay community in Singapore. It is an alarming state due to the island state's physical development and a political situation that could be deemed racist, apart from the attitude of the Malay community itself.
\end{abstract}

Keywords: history, historical fiction, Malays, Singapore, Malaysia 


\section{INTRODUCTION}

Historical sources have long been used by the authors of creative works as the sources for their writing because these share a characteristic with literary works: they contain a narrative element. A narrative is a sequence of events or a story. The historical events to which Isa Kamari draws attention in his novel Satu Bumi (One Earth) (1998) are those that occurred in Malaysia and Singapore from the 1940s to the 1950s.

The history of Malaysia and Singapore in Satu Bumi is juxtaposed with the romance between Aminah and Malik, while the dramatic backdrop of the novel is the Japanese Occupation and the British Colonial era. The romantic and dramatic backdrop of the novel is developed using a writing style that interweaves the past, present and future through the first person point of view. Imran, the character who acts as the narrator of the story, comes to Bidadari cemetery and there meets a gravedigger named Yassir. The novel developes out of this meeting, as Imran is drawn in by the stories told by Yassir, who is not merely a gravedigger but also a pragmatic former political activist.

Apart from Satu Bumi, Isa Kamari has written other historical novels such as Atas Nama Cinta (In the Name of Love) (2006) dan Rawa: Tragedi Pulau Batu Putih (Rawa: The Tragedy of Batu Putih) (2009). The novel Satu Bumi was chosen for this study because it does not merely discuss the history of Malaysia and Singapore from the time of the Japanese Occupation to the secession of Singapore from Malaysia but also predicts the future of the Malay community in Singapore, acting as a reminder to the Malay community in Malaysia. Therefore, its issues are still relevant in the present day.

\section{HISTORIOGRAPHY}

What is historiography? Historiography is a historical writing. How is it different from historical writing, fiction, or historical fiction? Historians on the whole are of the opinion that history is something "real", while fiction is something that is invented. This view of modern historical writing is that of R.G. Collingwood. This well-known historian specified four characteristics of modern historiography: it should be scientific, humanistic, rational and self-revelatory (Collingwood, 1973:18). "Self-revelatory" means that it should be objective, without the interference of the personal views of the historian. Is it possible for a historian to write without involving his personal views and ideology? Modernist historians defend the objectivity of historiography. However, postmodern historians are of the opinion that such objectivity 
cannot be upheld. Instead, there is a subjective element in historiography. Postmodern historians are unable to accept the modernist historians' view because there is a process of selection and interpretation of the historical material which is subject to the ideology or thought of the historian. Therefore, historiography is not objective since it contains an element of interpretation, and the opinion of the writer. Hayden White (1992:51) states:

Theorists of historiography generally agree that all historical narratives contain an irreducible and inexpungeable element of interpretation.

Can it then be said that historiography and historical fiction share some similarities? If one takes White's view, there is a similarity between historiography and the writing of historical novels because of the existence of an element of subjectivity which comes about as a result of the interpretation done by the writer. In the context of the writing of historical novels, there is not only an element of subjectivity of the part of the author but also the reader. The novel Satu Bumi provides the opportunity for readers to interpret the various elements of literature that can be found in it, which will in turn lead to different interpretations of meaning.

\section{HISTORICAL FICTION}

What is meant by historical fiction? Historical fiction is fiction in which certain historical events are important for the building of the plot or the development of the characters. All aspects of the writing of historrical fiction lead to "a sense of history", which can be seen from the author's perspective, character development and place setting. In other words, historical fiction such as historical novels, is fiction that is based on historical personages or events. Historical material, be it events or personages, are transmuted into a work of fiction. Therefore history becomes a fictional work through a creative process. The function of historical fiction is well-explained by:

Historical fiction is a window to the past through which we can view events and people that shaped the world, discover universal truth, and empathize with those who have gone before us and those currently living in similar circumstances. Through reading historical fiction, we make emotional connections between the past and present that aid us in understanding and valuing our own heritage and the world we lived. Historical fiction is a vehicle through which we can experience the past vicariously and understand human folly, greed, and aggression.

(Cole, 2009: 237) 
According to Cole, historical fiction is like a window whereby readers are able to look into important events in the past, while reading historical fiction will create an emotional connection between the past and present, and such a connection will cause readers to understand and appreciate their historical heritage and the world they live in. However, as a work of fiction, can fact and historical record behave according to the whims and fancies of the writer without any historical responsibility, that is, authenticity or accuracy? Can history be distorted in the name of history? Can literature take historical elements and act upon them arbitrarily, in the name of fiction? What kinds of forms of fiction are permissible in history, and accepted in Literature? If modern historical writing defended its objectivity, can literature, with its creative elements, provide its readers with a realistic depiction of history? Historical fiction defends its historical aspect but can be analysed from various angles, including the human angle. Through the creativity and imaginaiton of the writer, the historical material comes alive within a new frame, and this opens up a new perspective which lies somewhere between objectivity and subjectivity. Readers of Satu Bumi are able to build a new perspective based on the interpretation of the historical and literary elements in this novel.

\section{INTERTWINING HISTORY AND ROMANCE}

Satu Bumi contains elements of a romance, in that it involves the romantic relationship between Aminah and Jati. Imran, an engineer, goes to Bidadari cemetery to visit the grave of his grandmother, Aminah, because her grave, along with the others, is to be exhumed and relocated to a bigger plot in another area in order to make way for the building of a mass rapid transit (MRT) line. Imran feels as if he is sinning because he is involved with the exhumation of the graves of Malay Muslims and the demolishing of the nearby Bidadari mosque. Imran, as the engineer in charge of the development of the area, feels as if he is committing a sin because he has a connection to the area. Would he feel the same if he did not have such a connection to it? This is something for the reader to think about.

Aminah is a blood relation to Imran, but Imrans' connection is further extended to include the gravedigger, Yassir. It turns out that Yassir, also known as Jati, was once romantically involved with Imran's grandmother, who was a Chinese girl adopted by a Malay family-the family of Pak Durhakim. The reader is told that Jati, the son of Pak Durhakim, is Yassir, the gravedigger 
Imran encounters at the cemetery. Jati, or Yassir, falls in love with Aminah (whose Chinese name is Tan Swee Mei). However, Pak Durhakim betrothes Aminah to Malik, a young man whom she had never had any feelings for. In order not to disappoint her adoptive father, Aminah acquiesces to the match. This incident causes Jati to leave in a sulk. The romantic and sad love story between Yassir and Aminah can be seen in the following excerpt:

\begin{abstract}
"Saya akan menangis kalau abang tak ada." Airmata mengalir dari kelompok mata. Gadis itu merebahkan kepalanya di atas dada pemuda tersebut. Dengan perlahan rambut gadis itu diusap tangan yang gementar.

"Adik akan sentiasa di dalam ingatan abang." Dada bergemuruh dengan kesedihan dan nafsu. Dia memandang wajah gadis itu lalu mengucupkan dahinya. Tanpa kerelaan dia kemudian memaling muka lalu beredar. Terdengar esakan gadis yang melirihkan jiwa dan melemahkan kakinya. Dia terhenti sejenak. Dia hendak menoleh ke belakang. Tetapi dia takut dan cemas akan perasaannya sendiri. Dia kemudian berlari pantas. Entah mengejar atau dikejar kepiluan.
\end{abstract}

("I will cry if you are not here." Tears flowed from her eyes. The girl let her head fall against his chest. Slowly, he stroked her hair with shaking hands. "I will always remember you." Sadness and desire welled up in his chest. He looked at the girl and kissed her forehead. Without wanting to, he turned his face from her and walked away. He heard the soul-crushing, knee-weakening sobbing of the girl. He stopped briefly. He wanted to look back. But he was afraid of his own emotions. Then he ran off quickly, as if either chasing away or being chased by grief.)

(Isa Kamari,1998: 42-43)

The forbidden love between Jati and Aminah underlies one part of the novel. Intertwined with the romantic element is a historical element. Normally, a historical novel such as Satu Bumi does not depict historical elements in detail. However, the historical slant of the novel is seen through the sequence of events such as the Japanese Occupation and the British administration of Malaya, as the following passage shows:

Kebelakangan ini Yassir asyik memikirkan tentang Bintang Tiga yang telah memulakan kempen huru-hara di kampung-kampung. Dua minggu sebelum kuasa penuh diserahkan kepada British, Bintang Tiga yang bergerak melalui Tentera Anti-Jepun Nusa Utara, telah membunuh ramai orang Melayu yang disyaki telah menjadi tali-barut Jepun. Kerana ramai ahli Bintang Tiga 
itu berbangsa Cina, sejarah telah menyaksikan pertempuran kaum yang berdarah selama tiga belas hari. Pertempuran itu berlaku di merata Negara dari utara ke selatan.

Dan kini British pula memaksa gagasan Nusa Utara Union ke atas Tanah Melayu. Matlamat yang tersurat ialah menggabungkan semua kaum di Nusa Utara. Ramai ahli politik serumpun yang menganggap matlamat yang tersirat ialah menghapuskan hak istimewa Melayu dan penarikan kuasa mutlak raja-raja Melayu.

(Of late, Yassir had been thinking incessantly about the Bintang Tiga who had been on a terror campaign in the villages. Two weeks before control was officially handed back to the British, the Bintang Tiga, through the Northern Unit of the Anti-Japanese Army, had killed many Malays who had been suspected of having been lackeys of the Japanese. Because many of the Bintang Tiga were Chinese, history recorded a thirteen-day racial clash. The clashes took place in various parts of the country from north to south.

The British were now trying to force the idea of the Nusa Utara Union onto Malaya. Supposedly the aim was to unite all etnic groups in Nusa Utara. However, many local politicians considered the real aim to be the removal of the special rights of the Malays and the absolute power of the Malay rulers.)

(Isa Kamari, 1998:57-58)

The terrorism carried out by the Bintang Tiga is a part of the history of Malaysia and Singapore after the defeat of the Japanese and the return of the British army and the introduction of the idea of the Malayan Union. Apart from such historical names as Bintang Tiga, Isa Kamari has blurred out some historical names such by using the fictitious names Nusa Utara (Northern Region), which can be inferred to be Malaya and Nusa Utara Union, which probably refers to the Malayan Union. However, such fictitious names are not a problem for readers who are familiar with the history of Malaysia and Singapore. Isa Kamari uses the name Nusa Utara (Northern Region) and Nusa Selatan (Southern Region) to talk about two countries that have a long historical relationship. Nusa Utara is Malaysia and Nusa Selatan refers to Singapore. These two countries have similar histories. Indeed, at one time they were united, then separated, then united again and lastly separated until this day. The issue of the two countries being united and then separated receives a lot of attention from Isa Kamari. Not only that, the author also pays much attention to the Malay community of Singapore, which has become a minority on the island state. The Malays of Singapore and Malaysia come from the same roots. They are of the same religion and share the same culture but 
are separated by political boundaries. The Malays are an ethnic group that have a long and great history in this region (for further explanation on the Malays of the Southeast Asia region, see Sohaimi, 2012).

Although the Japanese Occupation in Malaya sparked violence, from the political point of view, it ignited the spirit of nationalism and a call for independence by some of the Malays. During the Japanese Occupation, Singapore and Malaya were governed as a single entity. However, upon the return of Singapore to the British, the island was governed as a separate territory. In Satu Bumi, Nusa Selatan (Singapore) is governed separately from Nusa Utara (Malaya) by the British after the surrender of the Japanese:

“... Nusa Selatan telah terpisah dari Rumpun Selat dan kini di bawah Pentadbiran Sivil Penjajahan Mahkota. Saya tau saudara tak suka dengan perpisahan ini."

(“...Nusa Selatan is now separated from the Straits Cluster and is now under the Civil Administration of the Crown Colonies. I know you do not like this separation.")

(Isa Kamari, 1998:64)

Indeed, Jati does not agree with the separation of Nusa Selatan from Nusa Utara. Both these regions are of the same origin in what in the novel is called the Straits Cluster. The rumours that Nusa Utara wishes to seek independence causes Jati to feel anxious. Jati is involved in several political parties such as SAWO and KERIS, which are moderate parties that are calling for the union between Nusa Selatan and Nusa Utara. His compatriots, Hashim, Malik and Ah Sin (the elder brother of Aminah, or Tan Swee Mei), are involved in the establishment of a military organization, the Bintang Tiga, to rebel against the British. However, Jati/Yassir prefers to be involved in political parties and to pursue the struggle through political means. The spirit of independence begins to burn within Jati/Yassir. This should be pursued jointly by Nusa Selatan and Nusa Utara. Why is he so adamant that both Nusa Selatan and Nusa Utara should be combined in this quest? According to Imran:

Yassir takut dengan kemerdekaan yang berasingan, Nusa Selatan akan semakin terpisah dari Nusa Utara. Padahal ramai orang Melayu Nusa Selatan termasuk dirinya menganggap perpisahan itu sebagai masalah pentadbiran saja, bukan dari segi jiwa. "Bagaimana dengan nasib kita bila Nusa Utara merdeka kelak?" 
(Yassir was afraid that with separate independence, Nusa Selatan would become further and further separated from Nusa Utara. Most Malays from Nusa Selatan, including himself, considered the separation to be merely political and not spiritual. "What will happen to us when Nusa Utara has achieved its independence?")

(Isa Kamari,1998:128)

Yassir thinks that if Nusa Utara achieves independence without Nusa Selatan, it will cause the Malays of Nusa Selatan to be neglected in terms of material development, such as the opportunity for a good education. Yassir is sure that the Malays will have better opportunities if Nusa Selatan is united with Nusa Utara. He has joined the political party KERIS, which is believed to be defending the rights and welfare of the Malays in Nusa Selatan. However, all such hopes are shattered when he realizes that KERIS is not serious about safeguarding the welfare of the Malays. Therefore, Yassir becomes a member of Partai Angkatan Baru (PAB), which he is certain will be able to defend the rights and welfare ofthe Malays:

Kerana itu, akhirnya dia mengambil keputusan berpindah ke PAB. Dia kesal KERIS telah mengecilkan amanah itu dan kepentingan orang Melayu di Nusa Selatan. Ternyata KERIS tidak mempunyai wawasan yang jelas terhadap nasib orang Melayu.

(Because of this, he finally decided to join the PAB. He was upset that KERIS took lightly their responsibility and the interests of the Malays in Nusa Selatan. Evidently, KERIS had no clear vision as to the future of the Malays.))

(Isa Kamari,1998:130)

In terms of historical background, KERIS can be seen to be $\mathrm{UMNO}^{1}$ (the United Malays National Organization-led by Tunku Abdul Rahman) while PAB (Partai Angkatan Baru) is the PAP. ${ }^{2}$

The tensions between UMNO and the PAP were racial tensions and they increased in intensity. Before the 1963 elections, UMNO had never contested in Singapore while the PAP had never contested on the Peninsula. However, in the 1963 state-level elections, UMNO supported the Malay candidates of the Singapore Alliance Party. UMNO campaigned for the Malay candidates who were in opposition to the PAP. Before this, there had been some kind of understanding that UMNO would not contest for elections in Singapore and the PAP would not contest on the Peninsula. The support of UMNO for the 
Malay candidates took place because the PAP under the leadership of Lee Kuan Yew had neglected the welfare of the Malays. However, the candidates supported by UMNO failed to succeed. Singaporeans, particularly the Malay community of Singapore, rejected any UMNO influence because UMNO leaders were believed to be holding a grudge against Singapore Malays:

Some Malay leaders had gone so far as to brand Malays who voted for the PAP as traitors to their race ... In 1963, many Malays in Singapore rejected UMNO's call to vote against the PAP, and in 1964, the Chinese electorate in Malaysia sent all but one of the PAP's candidates down to defeat.

(Baker, 2005:313)

The PAP was uneasy with the actions of UMNO, and in the 1964 elections, it contested for nine parliamentary seats in areas which had a Chinese majority. However, the PAP failed to get a foothold in the Peninsula as only one of its candidates managed to achieve victory. As a result of this, tensions between UMNO and the PAP escalated, and this situation mirrored the fact that a dangerous race politics was on the rise. This historical fact is fictionalized in that Yassir, who is depicted as a political activist for the Malays, rejects KERIS (UMNO) and supports the PAB (PAP), which he finds is able to promise something more pragmatic in order to bring progress to the Malay community. The reasons for rejecting KERIS (UMNO) has a link to the historical fact that the Malay community in Singapore rejected UMNO. Yassir holds the following opinion:

Langkah politik KERIS ketika itu hanyalah setakat memperjuangkan hak tanpa membangunkan masyarakat. PAB pula giat mengajukan saranansaranan yang berguna untuk masyarakat, terutama kepada kaum buruh. Yassir sedar, masyarakat Melayu sepertinya, masih terperangkap di dalam pekerjaan-pekerjaan yang dipandang rendah. Dengan ajuan hak samarata bagi setiap kaum, peluang masyarakatnya menikmati hasil pekerjaan yang lebih tinggi akan terbuka.

(The political steps taken by KERIS were only to defend rights without bringing any progress to the community. The PAB, however, continued to actively propose something that was useful, especially for the workers. Yassir realized, Malays like himself were still reduced to working in jobs considered to be of low status. By propsosing equal opportunities for all races, there would be more opportunities for his people to gain access to better jobs.)

(Isa Kamari,1998:131) 
Yassir also thinks that:

Segala yang pakcikjangkakan ternyata berlaku. KERIS lama-kelamaan hilang pengaruh. Orang Melayu dapat melihat KERIS tidak berkesan di dalam usaha-usaha mereka. Malah tiada program pembangunan yang diajukan KERIS untuk menyelesaikan masalah kerakyatan, pekerjaan dan perumahan. Masalah-masalah itu adalah yang asas dan penting pada masa itu.

(Everything that Uncle predicted came true. Little by little, KERIS lost support. The Malays saw that KERIS was ineffectual in its efforts. In fact, they had not proposed anything to solve issues such as citizenship, employment and housing. These were the pressing issues at the time.)

(Isa Kamari,1998:133)

Yassir is a Malay character who is fictionalized to represent the Malays who, in the history of Singapore, became full supporters of the PAP and believers in the concept "Malaysian Malay", rejecting the concept of Malay sovereignty which was being proposed by the "ultra-Malays" within UMNO.

In fact, the involvement of Yassir in KERIS in Nusa Utara does not go down well with the British administration because KERIS is seen to be a party that is gaining ground among the Malays, and is becoming increasingly outspoken in its opposition to the Nusa Utara Union. This is because the Malays are becoming more united and thus more influential under KERIS. The British, through the Special Branch, compel Yassir to return to Nusa Selatan and concentrate on the Malay community there. According to one of the Youngsters in the Special Branch, Yassir is needed in Nusa Selatan. In reality, the British intend to weaken Yassir's involvement with KERIS. This tactic is successful because Yassir then realizes that KERIS really does not do much for the Malays in comparison with the PAB. As a result, Yassir leaves KERIS and becomes a member of the PAB. Yassir sees the PAB as being capable of carrying out policies that benefit the lower classes, including the Malays. Apart from this, the PAB also calls for a unification between Nusa Selatan and Nusa Utara. Therefore, KERIS is slowly abandoned by the Malays, and by the 1963 elections, their support is for the PAB. KERIS, which is influential in Nusa Utara, is waning in influence in Nusa Selatan. Therefore, KERIS's resistance against the British is prevented from reaching Nusa Selatan. As a result: 
Dalam pilihan raya 1963, PAB berjaya sekali lagi mendapat banyak undi orang Melayu lantaran ramai yang beralih kepadanya. Hal ini kerana orang Melayu gembira PAB berjuang demi percantuman Nusa Selatan dengan Nusa Utara yang telah bertukar nama Nusa Secita.

(In the 1963 elections, the PAB once again received much support from the Malays, who had switched to this party. This was because the Malays were happy with the PAB's call towards the unification of Nusa Selatan with Nusa Utara under the name Nusa Secita (United Territories).

(Isa Kamari, 1998:133)

Yassir's political activism becomes more narrow as he is more and more influenced by the PAB which he sees as being capable of realizing two key areas important for the survival of the Malays: helping to improve the socio-economic status of the Malays and uniting Nusa Selatan and Nusa Utara. Yassir clearly is in support of Nusa Selatan becoming a part of Nusa Secita (which represents Malaysia).

Historically, 1963 saw the formation of Malaysia which consisted of Malaya, Sabah, Sarawak and Singapore. What were the reasons behind the PAP wanting Singapore to be a part of Malaysia? There are those who are of the opinion that this would enable Singapore to quickly gain independence from the British (http://ourstory.asia1.com.sg/merger/merger.html). Apart from political problems, economic problems also were a reason for the secession of Singapore from Malaysia. However, economic factors such as the cutting-off of economic contributions by Singapore to the Federal Government are not discussed in Satu Bumi (for further explanation on the economic factors, see Osborne, 1964).

In 1959, Singapore had achieved self-goverment but where internal security was concerned, the British were still in charge of Singapore. Therefore, becoming a part of Malaysia and then leaving the federation was an indirect move to gain independence from the British. This strategy proved successful because the unification did not last long. Many problems cropped up, such as racial clashes which caused death and injury, and generally brought about an atmosphere of disharmony. According to history:

Racial sensitivities were further inflamed by race riots that broke out between Malays and Chinese in Singapore in 1964. The army was called in and curfews were imposed to quell two episodes of violent disorder. In July and September that year, over five hundred people were injured in the 
intercommunal violence, and twenty-two people were killed. Singapore leaders saw the riots as the result of agitation by an extreme wing of UMNO, which was determined to undermine the legitimacy of the PAP government. Malay leaders blamed the riots on the PAP's use of sensitive racial issues to score political points.

(Baker, 2005:314)

The above excerpt states that two parties at the time, UMNO and the PAP, were in a power struggle and played off serious racial issues to the extent that there was rioting.

These historical race riots are also fictionalized in the novel. The fictional riots take place during the parade held on Prophet Muhammad's birthday:

Semangat perarakan bertukar menjadi semangat permusuhan yang nyata telah lama terperap dan kini meledak kerana dibakar dendam dan curiga. Suasana tidak terkawal selama beberapa hari. Rusuhan berlaku di merata kampung dan jalan raya.

(The celebratory spirit of the parade turned into clear enmity, which now exploded due to suppressed feelings of revenge and suspicion. The situation was out of control for several days. Riots took place everywhere, in kampongs and on the main roads.)

(Isa Kamari,1998:157)

The above passage explains that racial problems already existed in Nusa Selatan, especially among the Malays and Chinese. The unification of Nusa Selatan with Nusa Utara had exposed the problems of race politics that were welling up. These critical problems are made even more concrete through the depiction of a riot in which Aminah, a Chinese girl who has converted to Islam not because of marriage, but who is a faithful wife, a pious Muslimah, a loving and responsible mother, and a good daughter-in-law, is raped by a group of vengeful and hateful Chinese youngsters:

Pemuda-pemuda yang mula-mula terperanjat setelah mengetahui keturunannya, menjadi marah kerana tidak dapat menerima hakikat ada orang Cina masuk Melayu. Mereka memaki-hamun dan meludah mukanya. Api rusuhan dan dendam telah membakar pertimbangan akal. 
Rayuan belas kasihan tidak putus-putus diluahkan Aminah. Mula-mulanya dengan suara yang lemah. Kemudiannya dengan air mata. Wanita dan ibu yang kelelahan setelah digobel dan dicerohohi bertalu-talu dan bergantiganti, akhirnya pulang sebagai Aminah, diiringi ketawa serakah pembunuhpembunuhnya.

(The young men, who at first were surprised when learning of her descent, could not accept the idea that a Chinese would convert to Islam and "masuk Melayu" (become Malay). They swore at her, and spat in her face. The fire of hatred and opposition had burned out reason.

...

She unceasingly pleaded for mercy, at first feebly, then with tears. This woman and mother who was weak and weary after being violated over and over, returned home as Aminah, to the laughter of the men who had "killed" her.)

(Isa Kamari,1998:159-60)

Even though the rape is a hyperbolic incident, it shows the author's emphasis on the serious race politics which dominated the Singapore political scene at the time, and perhaps even today. The hatred of the Chinese towards the Malays had become so entranched that a Chinese woman who has converted to Islam, such as Aminah, is considered to have "become Malay", and this is unaccepetable to them. This incident makes the extreme nature of race conflict very apparent.

Historically, race politics was a major issue in Singapore in the 1960s. The destruction of Malay traditional villages to make way for housing projects was opposed by the Malays. They were not satisfied with the approach taken by the PAP. Therefore, several fights broke out in 1964 that caused race riots in which dozens were killed and hundreds were injured. The racial tensions were an important factor for the expulsion of Singapore from Malaysia on 9 August 1965:

Communal riots were looming. The peace of the peninsula and the continuance of Malaysia could not be ensured, unless Singapore left. There was no viable alternatives: separation of the island from Malaysia was announced when Parliament met on August 9th, 1965.

(Tregonning, 1972:276)

The expulsion incident is fictionalized to show that many pro-PAB Malays such as Yassir are unhappy when it happens. Ilham (Imran's father) becomes 
confused as he mourns not only because of the secession of Singapore from Malaysia but also the death of his mother and grandfather (Pak Durhakim):

Ibu dan datuk tidak bersamanya ketika Perdana Menteri mengisytiharkan kelontaran Nusa Selatan dari Nusa Secita setahun kemudiannya. Perdana Menteri menanggis ketika itu. Ilham tidak tahu mana satu yang lebih menyedihkan. Airmatanya telah kering kerana anak telah terpisah dari ibu. Terputuslah tembuni yang menalikan ikatan kasih, siasah dan sejarah. Selat Tebrau bergelora sentiasa. 9 Ogos 1965 adalah kaca duka dan retak cermin jiwanya.

(His mother and grandfather were not with him when the Prime Minister announced the expulsion of Nusa Selatan from Nusa Secita a year later. The Prime Minister cried. Ilham did not know which was the sadder event. His tears had dried up, as a child had been separated forever from its mother. The cord that had bound love, politics and history was now broken. The Tebrau Straits would be forever choppy. The 9th of August, 1965 was a reflection of the crack caused by sadness in the mirror of his soul.)

(Isa Kamari,1998:160)

The fictionalized expulsion of Nusa Selatan adds a deeper meaning to the relationship between Malaysia and Singapore, or in this case Nusa Selatan and Nusa Utara. It can be seen as a kind of "death", something that is irreversible. The hopes and dreams of Malays like Yassir who wished for the union to be a lasting one did not materialize. There are a lot of problems and issues. Apart from increasing racial tensions, there are problems affecting the Malay community from within. Yassir himself does not see the wider context for the necessity of Nusa Selatan to be united with Nusa Utara. Yassir is more influenced by short-term goals such as jobs and housing, which need to be addressed immediately through a unification of Nusa Selatan with Nusa Utara. Therefore, the PAB, which more effectively addresses these issues becomes more dependable than KERIS, which is more concerned with issues such as the history and identity of the Malays. Therefore, Malays like Yassir have been confused and cheated by a party such as the PAB who supposedly advocates equal opportunities. In the history of Singapore, in order to fulfil the housing needs in Singapore, many traditional Malay villages were destroyed. When these were destroyed, the history, identity and culture of the Malays was similarly destroyed. The issue of the destruction of identity and culture of the Malays is also fictionalized but the hidden issues are similar to those found in history. 
The exhumation of Malay graves and the demolishing of the Bidadari Mosque for the construction of a mass rapid transit line is no different from the destruction of Malay villages to make way for housing blocks and luxury apartments. Such type of development destroys the history and identity of the Malays. It can be said that the exhumation of graves and demolishing of mosques has a much bigger impact on Malay history and identity. It is not only the culture that is destroyed but also their religion that is under attack. Therefore, what is left to the Malays of Singapore? In this novel, the graves and Bidadari Mosque are symbolic of Malay survival. With these disappearing, the Malays themselves disappear. Who are the perpetrators? The Malays themselves. Those political activists who are devoid of idealism, and those citizens who do not know how to weigh effects are the perpetrators. Everything is destroyed, political power is lost and economic power is only found in their dreams. Indirectly, Isa Kamari predicts a bleak future for the Malays of Singapore:

Di sebalik keheningan malam, aku seolah-olah terdengar sayup-sayup bunyi gilisan siasah yang lama-kelamaan bertambah nyaring. Bunyi itu berlerung di dalam terowong jiwaku. Terasa seperti bunyi itu bersumber dari kacisan api yang memedihkan sumsum tulangku. Aku kenal bunyi itu. Bunyi gilisan roda besi keretapi gerak cepat, MRT yang mendesis dan mendengung di dalam terowong yang kulakarkan dan akan kubina. Terowong kemajuan yang menceroboh kesucian kehidupan. Terowong yang akan membongkar segala cerita dan rahsia jiwa-jiwa yang terkubur di sini.

(In the quiet of the night, it was as if I was hearing, far off, a screeching that became louder and louder. The sound echoed in the tunnel of my soul. It felt as if the sound came from a spark that shot through the marrow of my bones. I knew that sound. It was the sound of the MRT that would screech and scrape along in the tunnels that I was drafting and building. The tunnels of progress that encroached on the purity of life. The tunnels that would lay bare all the stories and secrets of the souls who had been buried here.)

(Isa Kamari,1998:163)

The bleak future of the Malays in Singapore is due to the Malays themselves. Yassir, who was once a political activist, has been misled by the political struggle of the PAB. And from a shallow-thinking political activist who has disappointed the Malay community, Yassir has now become a gravedigger who similarly brings disappointment to his community by 
carrying out the orders of the authorities to dig up the Malay graves, including the grave of the woman he once loved. This exhumation is a further effort to remove all traces of Malay history because graves are the remaining sign of Malay settlements after the villages have been destroyed. If Yassir represents the old faction among the Malays, "aku" or Imran represents the younger generation who are not much different. He has been tasked with the building of a tunnel where Bidadari cemetery once was, and with demolishing Bidadari Mosque in order to make way for an MRT line. Imran seems to perfect the task begun by Yassir to destroy the history and culture of the Malays in Nusa Selatan. Yassir and Imran seem incapable of controlling the situation, instead the situation controls them. Imran admits:

Dan aku terpukau dan mengah dengan bayangan kederasan keretapi otomat yang tidak berpemandu dan pacuan sejarah yang tidak kutahu kemanakah arah tujuannya. Seolah-olah terlepas daripada kawalan, tidak terkejar dan tiada penghujungnya. Selain kemanusiaan, apa lagi yang akan menjadi mangsa keburuannya.

(And I was mesmerized and breathtaken by the blaze of the speeding automated train and the speed of history, whose direction I could not foretell. It seemed out of control, out of my reach and without end. Other than humanity, what else would be its victim?)

(Isa Kamari,1998:163-64)

The actions of Yassir and Imran also reflect the reality of the Malays in Singapore who destroy their own history and identity. The fictionalized history allows the author to not only document history but also to make an interpretation and to predict the future, which is not possible for historians. The historical identity and culture of the Malays has been destroyed by the Malays themselves consciously and under pressure. The Malays need to be brave enough to expose the ruin caused by their own people. It is the responsibility of the Malays themselves to do this:

Terpulanglah pada manusia seperti penggali kubur yang bersamaku, untuk membongkar segala rahsia dan makna yang tersembunyi. Tidak kira pahit atau manis. Yang penting, seperti kata orang tua itu, hati kita harus bersih. Sebersih pasir putih.

(It remains up to people like the gravedigger beside me to expose all the secrets and the hidden meanings, be they bitter or sweet. What was important, 
as the old man had said, was to be clean. As cleans as a white grain of sand.)

(Isa Kamari,1998:164)

The courage to speak the truth must be accompanied by sincerity so that criticism and prediction that have been made about the future of the Malays remains free of personal agendas. The Malays cannot blame other people when it comes to this. It is the Malays themselves that destroy their own identity.

\section{CONCLUSION}

Satu Bumi is a piece of historical fiction. As historical fiction, it is a novel that based on some historical facts which have been fictionalized by the author. Therefore, this novel contains many elements of interpretation by the author, Isa Kamari. Reading this novel, interpretation is again made by the reader based on the literary elements in it. However, the reader's interpretation is limited by the scope of the novel. As such, the reader's interpretation is confined to discussing the history of Malaysia and Singapore. As a piece of historical fiction Satu Bumi presents the history of the relationship between Singapore and Malaysia which has been fictionalized with some elements of interpretation that lead not only to a documentation of the past but also a prediction of the future. Modern history is not able to do this because it requires objectivity. However, when history become fictionalized, objectivity is no longer an obstacle. Therefore, in Satu Bumi, the history of Malaysia and Singapore is given an additional dimension, that is, predicting a future situation. The problems of race politics played a part in the secession of Singapore from Malaysia and this continues to be a force in determining the future of the Malays in Singapore. Their identity continues to be eroded and they themselves are the agents of such erosion. Experience and reality should become a lesson to Malays in Malaysia to not aid in the erosion of their own identity.

\section{NOTES}

1 UMNO (United Malays National Organization) or PEKEMBAR (Pertubuhan Kebangsaan Melayu Bersatu) was established in 1946 in Johor Bahru. The first leader of this organization was Datuk Onn Jaafar, later it was Tunku Abdul Rahman. UMNO was established as a result of nationalistic feelings among the Malays. The early aims 
of this organization were not for political power but to protest the formation of the Malayan Union which had been put forward by the British after the Second World War, as merely another way for Britain to maintain control. The Malayan Union would put the Federated and Unfederated Malay states as well as two of the Straits Settlements (Penang and Melaka) under the administration of a British Governor, while Singapore would retain its status as a colony. Singapore was not included in the Malayan Union because the British were afraid that businessmen in Malaya would feel threatened if Singapore were a part of the union, as Singapore was economically far ahead, and might affect their business opportunities. Those in authority were against the idea of a Malayan Union. Furthermore, the geographical location of Singapore as a strategic port was favourable for the British. The British themselves were surprised that it was the Malays who were against the formation of the Malayan Union. In a referendum taken in 1962, the residents of Singapore opted to be united with Malaya (Malaysia had not been formed yet at this time). While Singapore was a part of Malaysia, UMNO wanted Singapore, which was under the administration of the PAP led by Lee Kuan Yew, to change its constitution in order safeguard the future of the Malays. The PAP rejected this. Instead, the PAP agreed to improve the lives of the Malays by providing job opportunities, education and housing schemes.

2 The PAP (People's Action Party) is a party that was formed in 1954 by Lim Chin Siong, Fong Swee Suan and Lee Kuan Yew. Its aims were to obtain independence from the British. Its three founders were all English-educated. The PAP contested in the first legislative election in 1955 and won three seats. In 1958, the constitution of Singapore (the Rendel Constitution) was amended and Singapore achieved self-government. In the 1959 elections, the PAP, under the leadership of Lee Kuan Yew, dominated Singapore politics and this would shape the direction of its government, as well as the direction of the future of the Malay community there. In 1963, Singapore became a part of Malaysia, and the PAP acted as an opposition party in the federation. There were tensions between the PAP and UMNO, the latter being the main party in the coalition formed by UMNO, MCA and MIC, which lasted until the expulsion of Singapore from Malaysia in 1965.

\section{REFERENCES}

Baker, Jim, 2005. A Popular History of Malaysia and Singapore. Second edition. Singapore: Marshall Cavendish Editions.

Cole, P.B., 2009. Young Adult Literature in the 21st Century. Boston: McGraw-Hill Higher Education.

Collingwood, R. G., 1973. The Idea of History. London: Oxford University Press. http://ourstory.asia1.com.sg/merger/merger.html (accessed on 11 November 2013). Isa Kamari, 1998. Satu Bumi. Singapore: Malaysia Press Sdn. Bhd.

Osborne, M.E., 1964. Singapore and Malaysia. Ithaca, New York: Department of Asian Studies, Cornell University.

Sohaimi Abdul Aziz, 2013. "Melayu daripada Satu Bangsa kepada Satu Etnik" in Ramli Abdul Samad, Melayu Mencapai Bintang. Penang: Persatuan Karyawan 
Pulau Pinang.

Tregonning, K.G., 1972. A History of Modern Malaysia and Singapore. Kuala Lumpur: Eastern Universities Press Sdn. Bhd.

White, H., 1992. Tropics of Discourse: Essays in Cultural Criticism. Fifth edition. Baltimore \& London: The Johns Hopkins University Press.

(Translated by Tanja Jonid) 